\title{
Our Short- and Long-Term Results of Laparoscopic Gastrectomy in Locally Advanced Gastric Cancer
}

\section{Lokal İleri Mide kanserinde Laparoskopik Gastrektomi Kısa ve Uzun Dönem Sonuçlarımız}

\author{
(1) Serdar Çulcul, (10 Cemil Yüksel1, (1) Salim Demirci2, (1) Ali Ekrem Ünal2, (1) Sancar Bayar2, (1) Afig Gojayev2 \\ IUniversity of Health Sciences Turkey, Dr. Abdurrahman Yurtaslan Ankara Oncology Training and Research Hospital, Clinic of Surgical Oncology, Ankara, Turkey \\ 2Ankara University Faculty of Medicine, Ankara, Turkey
}

\begin{abstract}
Objective: Gastric cancer is the fourth most common cause of death worldwide and the second most common cause of cancer-related deaths. Minimally invasive surgery now offers many advantages to both patients and surgeons all over the world. In our study, we presented our laparoscopic experiences in locally advanced gastric cancer (LAGC) surgery.

Method: Data of patients who underwent gastrectomy for LAGC in our clinic between January 2010 and January 2020 were retrospectively analyzed.

Results: Gastrectomy was performed on 288 patients with LAGC. Although laparoscopic surgery was conducted on 96 patients (33.3\%), open surgery was performed on 192 (66.7\%) patients. The mean operation time was $122.96 \pm 44.06$ (60-300) min. There was no statistically significant difference between the two groups in terms of anastomotic leakage $(p=0.724)$. The mean length of stay was 12.54 days in patients undergoing open surgery and 9.36 days in those undergoing laparoscopic surgery, with a statistically significant difference between the two groups $(p<0.001)$.

Conclusion: Although the learning curve is long and requires experience, we think that laparoscopic surgery is feasible in LAGC, as in early-stage gastric cancer.
\end{abstract}

Keywords: Gastric cancer, Laparoscopy, gastrectomy

\section{öz}

Amaç: Mide kanseri tüm dünyada en sık görülen dördüncü, kansere bağlı ölümlerin en sık ikinci nedenidir. Tüm dünyada artık minimal invaziv cerrahi hem hastalara hem de cerrahlara birçok avantaj sunmaktadır. Çalışmamızda lokal ileri mide kanseri (LiMK) cerrahisinde laparoskopik deneyimlerimizi sunduk.

Yöntem: Ocak 2010 - Ocak 2020 tarihleri arasında kliniğimizde LiMK nedeniyle gastrektomi yapılan hastaların verileri retrospektif olarak incelendi.

Bulgular: LiMK nedeniyle 288 hastaya gastrektomi yapıldı. Hastaların 92'si (\%31,9) kadın 196'sı (\%68,1) erkekti. Hastaların 96'sına (\%33,3) laparoskopik cerrahi yapıırken 192 'sine $(\% 66,7)$ ise açık cerrahi uygulanmıștır. Operasyon süresi ortalama $122,96 \pm 44,06(60-300)$ dakikaydı. Anastomoz kaçağı açısından

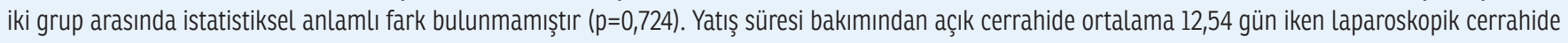
9,36 gün olup iki grup arasında istatistiksel anlamlı fark gösterilmiștir $(p<0,001)$.

Sonuç: Sonuç olarak öğrenme eğrisi uzun ve deneyim gerektirse de erken evre mide kanserinde olduğu gibi Limk'de laparoskopik cerrahinin uygulanabilir olduğunu düşünüyoruz.

Anahtar kelimeler: Mide kanseri, laparoskopi, gastrektomi

Cite as: Çulcu S, Yüksel C, Demirci S, Ünal AE, Bayar S, Gojayev A. Our Short- and Long-Term Results of Laparoscopic Gastrectomy in Locally Advanced Gastric Cancer. IKSSTD 2021;13(2):116-22 


\section{INTRODUCTION}

Gastric cancer is the fourth most common cause of death worldwide and the second most common cause of cancer-related deaths ${ }^{(1,2)}$. Radical gastrectomy with lymphadenectomy is the main treatment in resectable gastric cancers ${ }^{(3,4)}$. After Kitano et al. ${ }^{(5)}$ introduced laparoscopyassisted distal gastrectomy for early-stage gastric cancer in 1991, interest in laparoscopic gastric cancer surgery has grown considerably over the last two decades ${ }^{(6)}$.

Compared with open surgery, laparoscopy is associated with advantages including shorter recovery times, less intraoperative blood loss, and lower postoperative morbidity rates ${ }^{(7)}$. In recent meta-analyses of early-stage gastric cancer, similar oncological outcomes were obtained in short and long terms compared with open surgery ${ }^{(8,9)}$. Although laparoscopic surgery has become the standard of care in early-stage gastric cancer surgery, there is an ongoing debate on the treatment of locally advanced gastric cancer (LAGC) ${ }^{(7)}$. Recently, the number of studies showing the feasibility and safety of laparoscopic surgery in treating LAGC has increased ${ }^{(10,11)}$.

In our study, we have presented our experience in laparoscopic and open surgery in resectable LAGC in our clinic.

\section{METHOD}

Data of patients who underwent gastrectomy for LAGC in our clinic between January 2010 and January 2020 were retrospectively analyzed. The Ethics Committee of Ankara University Faculty of Medicine (il-48-21) granted the approval for the study. Patients who were younger than 18 years old, had distant metastasis, had a diagnosis other than adenocarcinoma, underwent surgery under emergency conditions, had positive peritoneal involvement, and had positive cytology were excluded from the study. The study included 288 LAGC patients. The demographic and clinicopathological data, postoperative complications, and overall survival of the patients were examined. The surgery and pathology reports, demographic characteristics, and overall survival of the patients were examined. Electronic radiological examination records of chest radiograms, computed tomography (CT), ultrasound, endoultrasound, magnetic resonance imaging, and positron emission tomography-CT were examined retrospectively. All data were retrieved through a retrospective review of patients' electronic files. The $8^{\text {th }}$ edition of the Union for International Cancer Control TNM classification system was used for staging.

\section{Statistical Analysis}

SPSS 25.0 software was used for data analysis. For descriptive analysis, quantitative variables were presented as mean \pm standard deviation and median (minimummaximum) and qualitative variables as the number of patients (percentage). The mean distributions of the quantitative data were tested using the Shapiro-Wilk test and histogram curves. For the quantitative variables, the difference between the categories of the qualitative variable with two categories was examined using the MannWhitney $U$ test for those who provided normal distribution assumptions and the Student's t-test for those who did not provide. The chi-squared test was used to evaluate the relationship between two qualitative variables. The statistical significance level was accepted as 0.05 .

\section{RESULTS}

Gastrectomy was performed in 288 patients with LAGC. Of the patients, 92 (31.9\%) were women, and 196 (68.1\%) were men. Although laparoscopic surgery was performed in 96 patients (33.3\%), open surgery was performed on 192 (66.7\%) patients. The mean age of the patients was 60.43 \pm 13.48 (22-93) years. The tumor was in the antrum in 134 (46.5\%) patients, corpus in 56 (19.4\%), and cardia in 98 (34.0\%). Subtotal and total gastrectomies were performed in $139(48.3 \%)$ and $149(51.7 \%)$ patients, respectively. The mean operation time was $122.96 \pm 44.06(60-300)$ min. Anastomotic leakage was observed in 17 (5.9\%) patients after the operation, and of them, $4(1.4 \%)$ were reoperated. The examination of the pathology specimens revealed positive surgical margins in 19 (6.6\%) patients. The characteristics of the patients are presented in Table 1.

The average survival time was $21.47 \pm 16.51$ months. Factors affecting survival were assessed using the KaplanMeier test. Patients undergoing laparoscopic gastrectomy showed statistically significantly better survival than those undergoing open surgery $(p<0.001)$. Survival was not found to be statistically significantly related to the presence or absence of an anastomotic leak in patients ( $p$ $=0.982$ ). Patients with positive surgical margins showed statistically significantly poorer survival $(p<0.001)$. When the relationship of survival to the general tumor stage and the $\mathrm{T}$ and $\mathrm{N}$-stages was examined, it was statistically shown that survival became poorer as tumor stages advanced in the three groups, with p-values of $<0.001,0.001$, and 0.001 , respectively. The survival analyses are shown in Table 2 and Figure 1-5. 
Total and subtotal gastrectomies were performed, respectively, on 106 and 86 patients via open surgery and 33 and 63 patients via laparoscopy, with a statistically significant difference $(p=0.001)$. There was no statistically significant difference in the occurrence of anastomotic leaks between the two groups $(p=0.724)$. The mean lengths of stay were 12.54 and 9.36 days in patients undergoing open and laparoscopic surgery, respectively, with a statistically significant difference between the two groups ( $p<0.001$ ). The mean operative times were 108.54 and $151.82 \mathrm{~min}$ in the open and laparoscopic surgery groups, respectively, with a statistically significant difference between the two groups ( $p$ $<0.001$ ). The relationship between the operation type and other factors is shown in Table 3. The number of removed lymph nodes was $24.20 \pm 9.35$ in the laparoscopy group and $25.7 \pm 10.59$ in the open surgery group, without a statistically significant difference between the two groups $(p=0.234)$.

\section{DISCUSSION}

The Japanese gastric cancer treatment guidelines recommend gastrectomy and D2 dissection for curative treatment of LAGC (11). The D2 lymph node dissection

\section{Table 1. Patient characteristics}

\begin{tabular}{|c|c|c|c|c|c|}
\hline Variables & & & Laparoscopic & Open & P value \\
\hline Age (years) & Mean \pm SD & $60.43 \pm 13.48$ & 58.4 & 62.46 & 0.284 \\
\hline Survival & Mean \pm SD & $21.47 \pm 16.51$ & 26.4 & 16.54 & $<0.001$ \\
\hline \multirow{2}{*}{ Sex, $n(\%)$} & Male & $196(68.1)$ & 50 & 146 & 0.56 \\
\hline & Female & $92(31.9)$ & 46 & 46 & 0.62 \\
\hline \multirow{3}{*}{ Location, n (\%) } & Antrum & $134(46.5)$ & 44 & 90 & \\
\hline & Corpus & $56(19.4)$ & 18 & 38 & \\
\hline & Cardia & $98(34.0)$ & 34 & 64 & \\
\hline \multirow{2}{*}{ Operation, n (\%) } & Laparoscopy & $96(33.3)$ & & & \\
\hline & Open & $192(66.7)$ & & & \\
\hline \multirow{2}{*}{ Blood transfusion, $\mathrm{n}(\%)$} & Yes & $68(23.6)$ & 30 & 38 & 0.14 \\
\hline & No & $220(76.4)$ & 66 & 134 & \\
\hline \multirow{2}{*}{ Mortality, n (\%) } & No & $103(35.9)$ & 33 & 70 & 0.11 \\
\hline & Yes & $184(64.1)$ & 63 & 121 & \\
\hline \multirow{2}{*}{ Operation type, n (\%) } & Total gastrectomy & $139(48.3)$ & 33 & 106 & 0.001 \\
\hline & Subtotal gastrectomy & $149(51.7)$ & 63 & 86 & \\
\hline Operation time & Mean \pm SD & $122.96 \pm 44.06$ & $151.82 \pm 51.91$ & $108.54 \pm 30.91$ & $<0.001$ \\
\hline Oral intake & Mean \pm SD & $3.23 \pm 1.59$ & 2.4 & 4.06 & 0.82 \\
\hline Total lymph node, n (\%) & Mean \pm SD & $25.2 \pm 10.20$ & 24.2 & 25.7 & 0.234 \\
\hline Metastatic lymph node, n (\%) & Mean \pm SD & $7.27 \pm 8.11$ & 8 & 6.54 & 0.63 \\
\hline \multirow{2}{*}{ Anastomotic leak, n (\%) } & No & $271(94.1)$ & 91 & 180 & \\
\hline & Yes & $17(5.9)$ & 5 & 12 & 0.724 \\
\hline \multirow{2}{*}{ Reoperation, $\mathrm{n}(\%)$} & No & $284(98.6)$ & 95 & 189 & \\
\hline & Yes & $4(1.4)$ & 1 & 3 & 0.44 \\
\hline \multirow{2}{*}{ Surgical margin, $\mathrm{n}(\%)$} & Negative & $269(93.4)$ & 90 & 179 & \\
\hline & Positive & $19(6.6)$ & 6 & 13 & 0.26 \\
\hline \multirow{2}{*}{ T-stage, n (\%) } & 3 & $134(46.7)$ & 55 & 79 & 0.2 \\
\hline & 4 & $153(53.3)$ & 40 & 113 & 0.21 \\
\hline \multirow{4}{*}{$\mathrm{N}$-stage, n (\%) } & 0 & 59 (20.5) & 19 & 39 & 0.13 \\
\hline & 1 & $54(18.8)$ & 20 & 36 & 0.22 \\
\hline & 2 & $64(22.2)$ & 21 & 42 & 0.2 \\
\hline & 3 & 111 (38.5) & 36 & 75 & 0.2 \\
\hline
\end{tabular}


leads to better oncological outcomes, but it is associated with technical difficulties and increased postoperative morbidity ${ }^{(12)}$. Many randomized controlled studies have shown the superiority of laparoscopic surgery over open surgery in early gastric cancer ${ }^{(13,14)}$. However, there is still an ongoing debate about the role of laparoscopy in

Table 2. Kaplan-Meier survival analysis

\begin{tabular}{|c|c|c|c|}
\hline & Lifetime & \multirow{2}{*}{$P$ value } \\
\hline & & Mean \pm SD & \\
\hline \multicolumn{2}{|l|}{ General } & $31.23 \pm 1.78$ & - \\
\hline \multirow{2}{*}{ Operation } & Open & $26.15 \pm 1.82$ & \multirow{2}{*}{$<0.001$} \\
\hline & Laparoscopy & $45.82 \pm 4.03$ & \\
\hline \multirow{2}{*}{ Stage } & 2 & $50.20 \pm 3.58$ & \multirow{2}{*}{$<0.001$} \\
\hline & 3 & $22.20 \pm 1.42$ & \\
\hline \multirow{2}{*}{ Surgical margin } & Negative & $32.85 \pm 1.86$ & \multirow{2}{*}{$<0.001$} \\
\hline & Positive & $7.68 \pm 1.29$ & \\
\hline \multirow{2}{*}{ T-stage } & 3 & $43.59 \pm 2.84$ & \multirow{2}{*}{$<0.001$} \\
\hline & 4 & $19.90 \pm 1.48$ & \\
\hline \multirow{4}{*}{ N-stage } & 0 & $52.60 \pm 4.30$ & \multirow{4}{*}{$<0.001$} \\
\hline & 1 & $31.60 \pm 3.62$ & \\
\hline & 2 & $30.18 \pm 2.94$ & \\
\hline & 3 & $18.40 \pm 1.52$ & \\
\hline
\end{tabular}

\section{Operation Type}
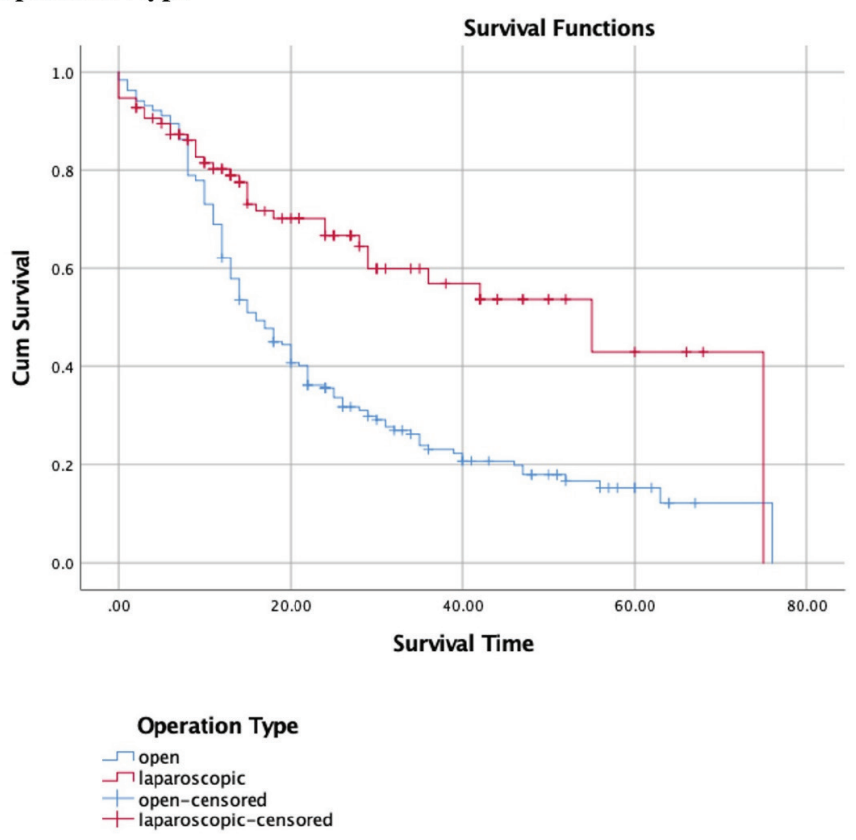

Figure 1. The relationship between operation type and survival treating LAGC because of the concerns that laparoscopic instruments may traumatize large tumors and metastatic lymph nodes, causing peritoneal transplantation and port site metastasis, and that prolonged operation times may deteriorate immune defense systems and facilitate

Stage

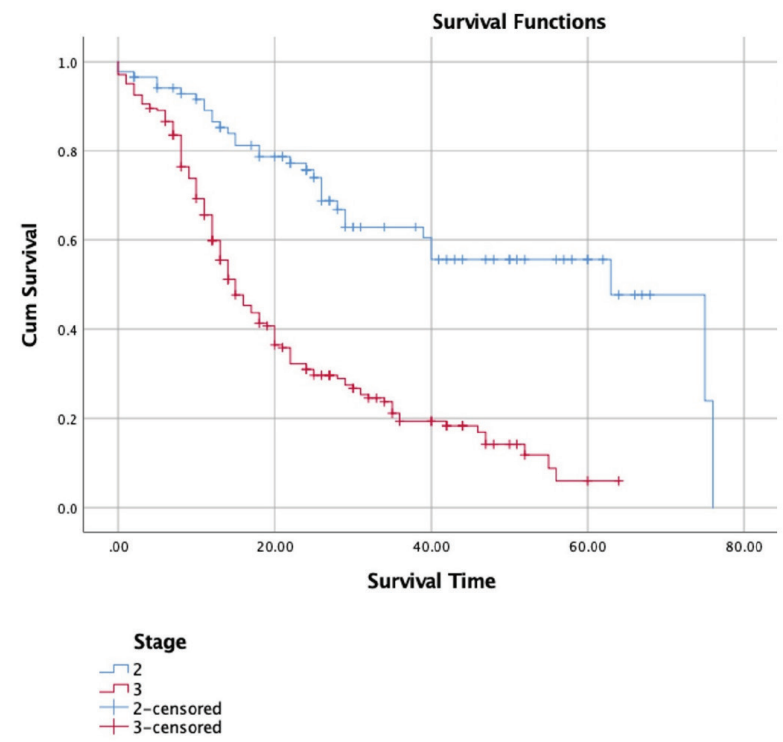

Figure 2. The relationship between stage and survival

\section{Surgical Margin}
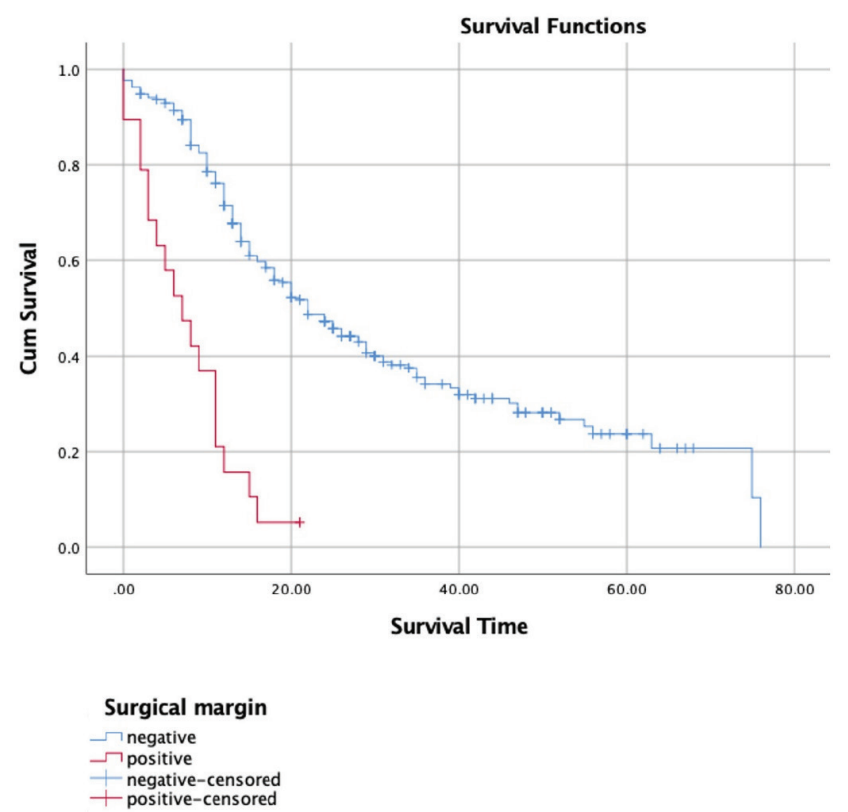

Figure 3. The relationship between surgical margin and survival 
Table 3. The relationship between the operation type and factors

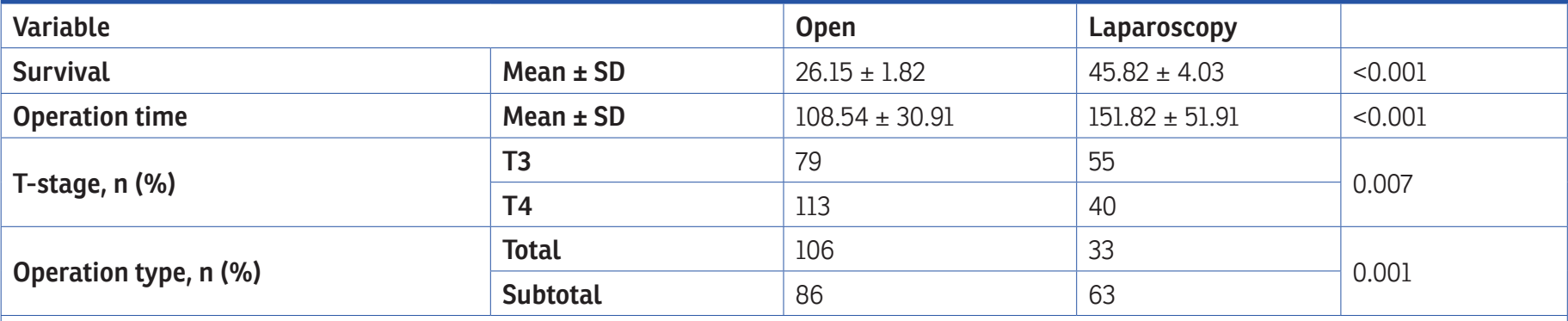

SD: Standard deviation

T Stage
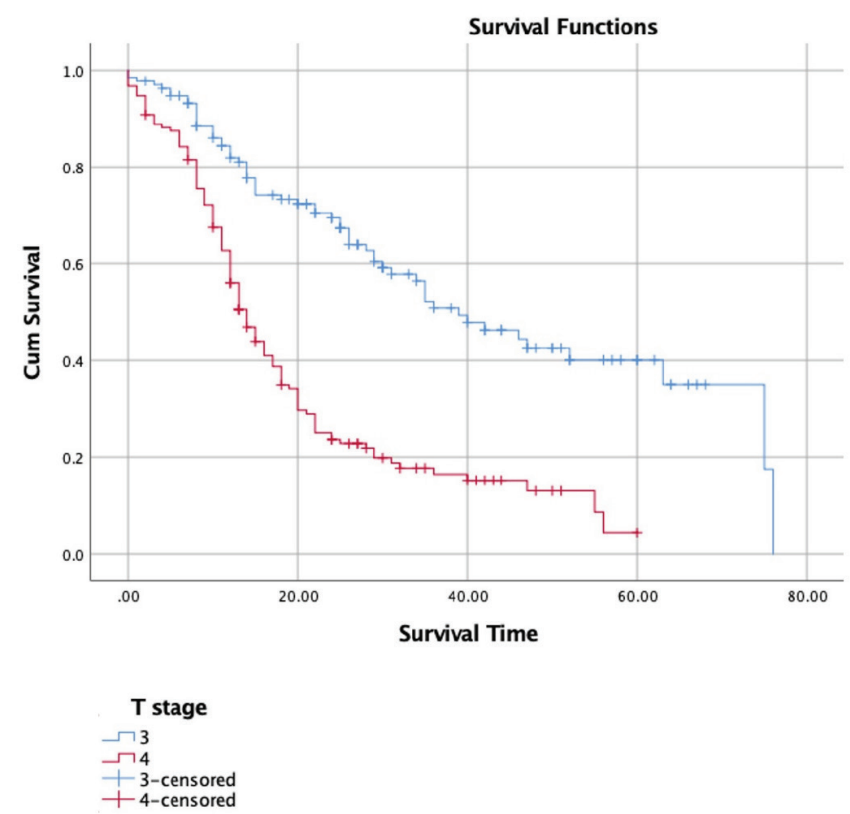

Figure 4. The relationship between T-stage and survival

tumor progression ${ }^{(15,16)}$. In the literature, there has been an increasing number of studies showing the feasibility and safety of laparoscopic surgery in LAGC ${ }^{(10,11)}$. We prefer performing laparoscopic surgery routinely in our clinic in the absence of contraindications.

Park et al. compared laparoscopic and open surgery in LAGC in 204 patients and found that the mean operative times were $257 \pm 86.7$ and $183.0 \pm 52.5$ min, respectively, with a statistically significant difference between the two groups ( $p$ $<0.001)^{(17)}$. Another study compared open and laparoscopic surgery and reported a mean operative time of 389 min for laparoscopic surgery ${ }^{(18)}$. In our study, the mean operative

\section{N Stage}
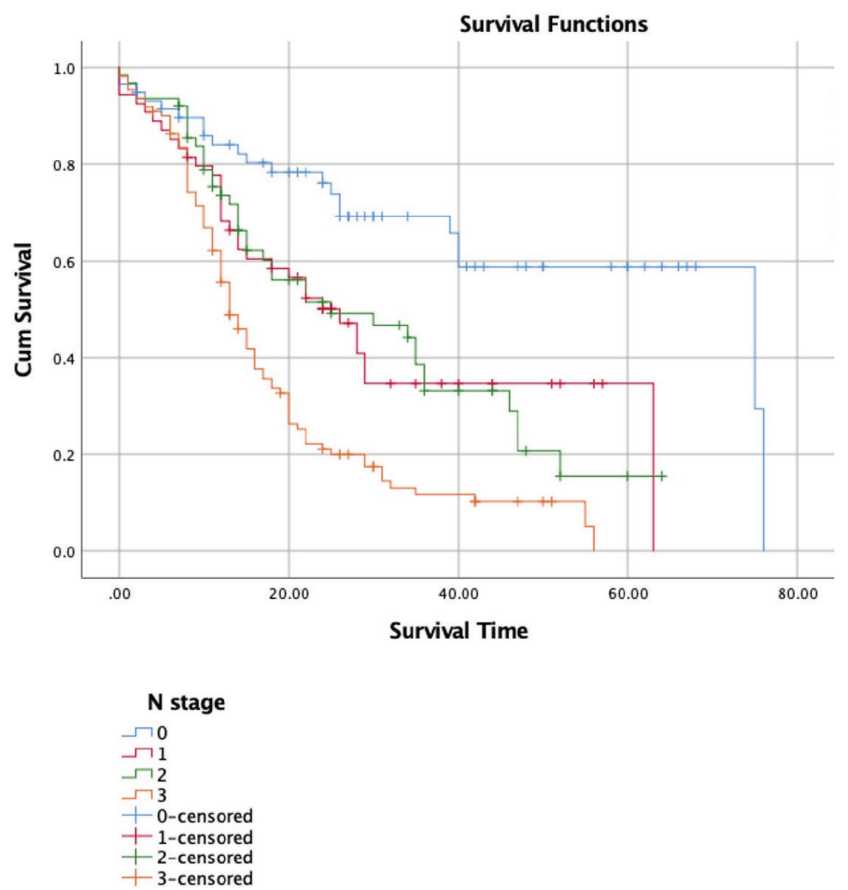

Figure 5. The relationship between $\mathrm{N}$-stage and survival

time in laparoscopic surgery was $151.82 \pm 51.91 \mathrm{~min}$, which was shorter than in the literature. We think that this is because of our low laparoscopic total gastrectomy cases and increased experience over the years.

The main concern in LAGC surgery is the risk of failing to perform an efficient D2 dissection in laparoscopic surgery. Despite reports of the low number of dissected lymph nodes in the early stages of transition to laparoscopic surgery than open surgery ${ }^{(5,19)}$, it has been shown that the numbers of removed lymph nodes have become similar across open and laparoscopic surgery along with the increasing surgeons' experiences and technological advancements ${ }^{(20,21)}$. In our 
study, there was no difference between the two groups $(p=0.234)$. Additionally, because laparoscopy allows for a comfortable viewing angle and easier accessibility using flexible instruments, we think that laparoscopy provides comfort to the surgeon, especially in dissecting lymph node stations such as $8 p$ and 12p, as classified under the Japanese Gastric Cancer Association criteria.

In general, laparoscopic surgery has advantages such as shorter hospital stay, early onset of oral intake, and less use of blood products ${ }^{(22)}$. In our study, the length of hospital stay was shorter in the laparoscopic group than in the open surgery group, and the difference between the two groups was statistically significant $(p<0.001)$. Between the two groups, we did not find a statistically significant difference in the occurrence of anastomotic leaks, which could lead to a prolonged hospital stay and increased mortality and morbidity $(p=0.724)$. Although we know that bowel movements begin earlier in laparoscopic surgery, we prefer to switch to oral feeding in 3.23 days on average in the early postoperative period after laparoscopic and open surgery in our clinical practice.

A few studies are reporting the long-term results of laparoscopic and open surgery in the treatment of LAGC. Qiu et al. ${ }^{(23)}$ did not find a difference in the 3-year overall survival between the two groups. Choi et al. ${ }^{(24)}$ did not report any statistically significant difference in long-term diseasefree survival and overall survival. In their meta-analysis, Quan et al. ${ }^{(25)}$ did not detect a difference in the diseasefree and overall survival between the two groups. Similar to our study, we reported a better mean survival time of $21.47 \pm 16.51$ months and better survival after laparoscopic surgery, with statistical significance $(p<0.001)$. We attribute this difference to the higher number of patients in the open surgery group and the higher number of patients who did not receive adjuvant therapy or who were lost to follow-up in the open surgery group. Meanwhile, we found that the $T$ and $\mathrm{N}$-stages and surgical margin positivity were the factors affecting survival.

\section{Study Limitations}

The limitations of our study include the retrospective design, significant difference in the number of patients between the two groups, assessment of electronically retrieved data only, inadequate data to find out whether the patients who were lost to follow-up received adjuvant therapy or not, missing data to analyze neoadjuvant therapy outcomes, and lack of evaluation of the factors that could act on mortality and morbidity in laparoscopic and open surgery including obesity, comorbid diseases, benign causes, and abdominal surgery history.

\section{CONCLUSION}

In conclusion, despite the long and experience-requiring learning curve in laparoscopic surgery, we prefer laparoscopic surgery for treating LAGC, similar to our clinical practice in early gastric cancers, especially because of comfortable accessibility to difficult-to-reach locations, early postoperative recovery, and less postoperative pain.

Ethics Committee Approval: The Ethics Committee of Ankara University Faculty of Medicine (i1-48-21) granted the approval for the study.

Informed Consent: Retrospective study.

Conflict of Interest: No conflict of interest was declared by the authors.

Financial Disclosure: The authors declared that this study received no financial support.

Etik Kurul Onayı: Ankara Üniversitesi Tıp Fakültesi Etik Kurulu'ndan (i̇l-48-21) çalışma için onay alınmıștır.

Hasta Onayı: Retrospektif çalışmadır.

Çıkar Çatıșması: Yazarlar tarafından çıkar çatışması bildirilmemiştir.

Finansal Destek: Yazarlar tarafından finansal destek almadıkları bildirilmiştir.

\section{REFERENCES}

1. Kamangar F, Dores GM, Anderson WF. Patterns of cancer incidence, mortality, and prevalence across five continents: defining priorities to reduce cancer disparities in different geographic regions of the world. Journal of clinical oncology. 2006;24(14):2137-50.

2. Mukherjee S, Hurt CN, Bridgewater J, Falk S, Cummins S, Wasan H, et al. Gemcitabine-based or capecitabine-based chemoradiotherapy for locally advanced pancreatic cancer (SCALOP): a multicentre, randomised, phase 2 trial. The lancet oncology. 2013;14(4):317-26.

3. Sasako M, Sano T, Yamamoto S, Kurokawa Y, Nashimoto A, Kurita A, et al. D2 lymphadenectomy alone or with para-aortic nodal dissection for gastric cancer. New England Journal of Medicine. 2008;359(5):453-62.

4. Songun I, Putter $H$, Kranenbarg EM-K, Sasako M, van de Velde CJ. Surgical treatment of gastric cancer: 15-year follow-up results of the randomised nationwide Dutch DID2 trial. The lancet oncology. 2010;11(5):439-49.

5. Kitano S, Iso Y, Moriyama M, Sugimachi K. Laparoscopy-assisted Billroth I gastrectomy. Surgical Laparoscopy Endoscopy \& Percutaneous Techniques. 1994;4(2):146-8.

6. Bracale U, Pignata G, Lirici MM, Hüscher CG, Pugliese R, Sgroi G, et al. Laparoscopic gastrectomies for cancer: The ACOI-IHTSC national guidelines. Minimally Invasive Therapy \& Allied Technologies. 2012;21(5):313-9. 
7. Chen X-Z, Hu J-K, Yang K, Wang L, Lu Q-C. Short-term evaluation of laparoscopy-assisted distal gastrectomy for predictive early gastric cancer: a meta-analysis of randomized controlled trials. Surgical Laparoscopy Endoscopy \& Percutaneous Techniques. 2009;19(4):27784.

8. Yasunaga $\mathrm{H}$, Horiguchi $\mathrm{H}$, Kuwabara K, Matsuda S, Fushimi K, Hashimoto $\mathrm{H}$, et al. Outcomes after laparoscopic or open distal gastrectomy for early-stage gastric cancer: a propensity-matched analysis. Annals of surgery. 2013;257(4):640-6.

9. Best LM, Mughal M, Gurusamy KS. Laparoscopic versus open gastrectomy for gastric cancer. Cochrane Database of Systematic Reviews. 2016(3)

10. Nam BH, Kim Y-W, Reim D, Eom BW, Yu WS, Park YK, et al. Laparoscopy assisted versus open distal gastrectomy with D2 lymph node dissection for advanced gastric cancer: design and rationale of a phase II randomized controlled multicenter trial (COACT 1001). Journal of gastric cancer. 2013;13(3):164-71.

11. Association JGC. Japanese gastric cancer treatment guidelines 2010 (ver. 3). Gastric cancer. 2011;14(2):113-23.

12. Barreto SG, Sirohi B. Why should we perform a D2 lymphadenectomy in gastric cancer? : Future Medicine; 2017.

13. Kim W, Kim H, Han S, Kim M, Hyung W, Ryu S, et al. Korean Laparoendoscopic Gastrointestinal Surgery Study (KLASS) Group. Decreased morbidity of laparoscopic distal gastrectomy compared with open distal gastrectomy for stage I gastric cancer: short-term outcomes from a multicenter randomized controlled trial (KLASS-01). Ann Surg. 2016;263(1):28-35.

14. Kitano S, Shiraishi N, Uyama I, Sugihara K, Tanigawa N, Group JLSS. A multicenter study on oncologic outcome of laparoscopic gastrectomy for early cancer in Japan. Annals of surgery. 2007;245(1):68.

15. Sasako M. Is there role for laparoscopic gastrectomy for advanced gastric cancer. European Journal of Surgical Oncology. 2017;43(6):965-

16. Ure B, Niewold T, Bax N, Ham M, Van Der Zee D, Essen G. Peritoneal, systemic, and distant organ inflammatory responses are reduced by a
Laparoscopic approach and carbon dioxide vs air. Surgical Endoscopy and Other Interventional Techniques. 2002;16(5):836-42.

17. Park YK, Yoon Ã, Kim Y-w, Park Y, Ryu KW, Lee Y-j, et al. Laparoscopyassisted versus Open D2 Distal Gastrectomy for.

18. Nakauchi M, Suda K, Nakamura K, Shibasaki S, Kikuchi K, Nakamura T, et al. Laparoscopic subtotal gastrectomy for advanced gastric cancer: technical aspects and surgical, nutritional and oncological outcomes. Surgical Endoscopy. 2017;31(11):4631-40.

19. Memon MA, Khan S, Yunus RM, Barr R, Memon B. Meta-analysis of laparoscopic and open distal gastrectomy for gastric carcinoma. Surgical endoscopy. 2008;22(8):1781-9.

20. Tokunaga M, Hiki N, Fukunaga $T$, Nohara K, Katayama $H$, Akashi $Y$, et al. Laparoscopy-assisted distal gastrectomy with D2 lymph node dissection following standardization-a preliminary study. Journal of Gastrointestinal Surgery. 2009;13(6):1058-63.

21. Sato $H$, Shimada $M$, Kurita $N$, Iwata $T$, Nishioka $M$, Morimoto $S$, et al. Comparison of long-term prognosis of laparoscopy-assisted gastrectomy and conventional open gastrectomy with special reference to D2 lymph node dissection. Surgical endoscopy. 2012;26(8):2240-6.

22. Nakauchi M, Suda K, Kadoya S, Inaba K, Ishida Y, Uyama I. Technical aspects and short-and long-term outcomes of totally laparoscopic total gastrectomy for advanced gastric cancer: a single-institution retrospective study. Surgical endoscopy. 2016;30(10):4632-9.

23. Qiu J, Pankaj P, Jiang H, Zeng Y, Wu H. Laparoscopy versus open distal gastrectomy for advanced gastric cancer: a systematic review and metaanalysis. Surgical Laparoscopy Endoscopy \& Percutaneous Techniques. 2013;23(1):1-7.

24. Choi YY, Bae JM, An JY, Hyung WJ, Noh SH. Laparoscopic gastrectomy for advanced gastric cancer: Are the long-term results comparable with conventional open gastrectomy? A systematic review and metaanalysis. Journal of surgical oncology. 2013;108(8):550-6.

25. Quan Y, Huang A, Ye M, Xu M, Zhuang B, Zhang P, et al. Comparison of laparoscopic versus open gastrectomy for advanced gastric cancer: an updated meta-analysis. Gastric Cancer. 2016;19(3):939-50. 